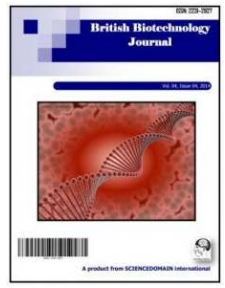

British Biotechnology Journal

16(2): 1-4, 2016, Article no.BBJ.29300

ISSN: 2231-2927, NLM ID: 101616695

SCIENCEDOMAIN international

www.sciencedomain.org

\title{
Biddulphia (Odontella) sp. Isolated from the Seawater of Kayalpattinam Coastal Area, Gulf of Mannar and Maintained in Tuticorin Research Centre of ICAR-CMFRI
}

\author{
S. Lakshmana Senthil ${ }^{1}$, C. P. Suja ${ }^{1^{*}}$, B. Koncies Mary ${ }^{1}$ and P. Vijayagopal ${ }^{2}$ \\ ${ }^{1}$ Central Marine Fisheries Research Institute, Tuticorin Research Centre, Tuticorin-628001, TN, India. \\ ${ }^{2}$ Central Marine Fisheries Research Institute, Kochi- 682 018, Kerala, India.
}

Authors' contributions

This work was carried out in collaboration between all authors. Author SLS designed the study, performed the experiments, wrote the protocol and wrote the first draft of the manuscript. Author CPS supervised the entire study and author BKM supported the analyses of the study. Author PV managed the critical corrections. All authors read and approved the final manuscript.

Article Information

DOI: $10.9734 / \mathrm{BBJ} / 2016 / 29300$

Editor(s):

(1) Cosmas Nathanailides, Dept Aquaculture \& Fisheries, TEI of Epirus, Greece. Reviewers:

(1) Anonymous, Bowen University, Iwo, Osun State, Nigeria. (2) Uchechukwu Enyidi, Michael Okpara University of Agriculture, Nigeria. Complete Peer review History: http://www.sciencedomain.org/review-history/16458

Short Communication

Received $1^{\text {st }}$ September 2016

Accepted $27^{\text {th }}$ September 2016 Published $6^{\text {th }}$ October 2016

\section{ABSTRACT}

Aim: Present study was aimed to isolate marine algae from the sea water samples of Kayalpattinam Coastal area, Gulf of Mannar.

Methodology: Seawater samples were collected for the isolation of phytoplankton from the Kayalpattinam Coastal area, Tuticorin on May 2016. The collected seawater was maintained in Walne medium with optimum conditions (light intensity of $1000 \mathrm{Lux}, \mathrm{pH}$ of 8.2-8.7, temperature of $18-25^{\circ} \mathrm{C}$ and salinity of $35 \mathrm{ppt}$ ) for obtaining maximu $\mathrm{m}$ growth. After the visible change observed, microscopic observation was carried out.

Results: Microscopic observation revealed that the sample contained Biddulphia (Odontella) sp. which is also known as Chinese Diatom. There were significant numbers of the species. It is further confirmed by the morphological identification. It has been maintained in phytoplankton repository of Tuticorin Research Centre, ICAR-CMFRI for sale and research. Cells are observed either in 
isolated or in the colony which are organized in straight lines or in a zigzag pattern and they are yellow/brown in colour. The size is measured and varied from 25 to $40 \mu$.

Conclusion: Biddulphia (Odontella) sp. has been widely used as a feed for zooplanktons in aquaculture industry. This is the first report of method to isolate and cultivate this species. Further more research is needed in order to investigate the potential utilization of this species in medicinal, nutritional and other possible useful properties of Biddulphia (Odontella) sp.

Keywords: Biddulphia sp.; Odontella sp.; diatom; feed.

\section{INTRODUCTION}

Phytoplankton which is known as microalgae, are analogous to plants in the aspect of photosynthesis. Phytoplankton is the most important indicator for the water quality and other important parameters in any aquatic system [1].

It has been separated into dinoflagellates and diatoms. Dinoflagellates are having tail, or flagella, to migrate through the water and covered with complex shells. Diatoms are microscopic, unicellular algae that are rich in marine and fresh water aqua systems. Many phytoplankton comes under diatom genera which are important in the food chain [2].

Many of the methods and basic culture medium have been used for culturing marine and fresh water algae. Algal culture techniques by using different medium have been described in several earlier books and articles [3-5] and Walne medium is the most frequently used media for culturing marine micro algae [6].

Biddulphia (Odontella) sp. was first observed in European waters in 1889 and it was moved to British waters by 1906. It was named as Chinese Diatom because the Chinese Sea was the first place in which it was described in 1866. It has recently been found in UK and European waters were likely introduced from the Red Sea or the Indian Ocean [7].

Biddulphia sp. is a marine centric diatom frustules and its basionym is Odontella sp. This species was commonly found in Pacific Ocean near the sea shore (Oahu, Hawaii). Biddulphia $s p$. typically forms a light brown crust on seaweeds or rocks in the marine systems. It has been deposited as a crust on aquarium walls. The body or frustule is composed of two halves which fit tightly together. The cell walls contain silica dioxide (glass) which are preserved in deposits known as diatomaceous earth. Once hardened into rock which is called diatomite. It can be used for many purposes including filters, fillers and abrasives [1].

Objectives of the present study are: to collect the seawater; to maintain the seawater sample in Walne medium; to isolate important algae from the collected water.

\section{EXPERIMENTAL DETAILS}

\subsection{Study Area}

Seawater samples were collected for the isolation of phytoplankton from the Kayalpattinam Coastal area, Tuticorin on May 2016 with the Latitude of 893' $\mathrm{N}$ and Longtitude of 7890' $\mathrm{E}$ (Fig. 1).

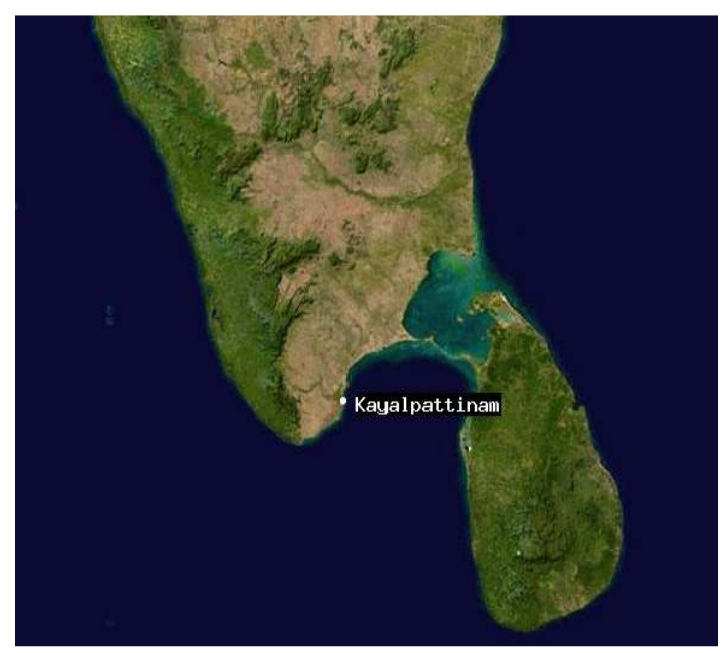

Fig. 1. Study area

\subsection{Collection and Maintenance of Seawater Sample}

Seawater samples were collected in sterile glass containers and were stored at $18-25^{\circ} \mathrm{C}$ until use. The water samples containing microalgae were inoculated and maintained in Walne medium with silicate in conical flasks at $18-25^{\circ} \mathrm{C}$, salinity of 27-35 ppt with white fluorescent light at an 
intensity of 1000 lux. Growth of microalgae was observed regularly by microscope.

\section{RESULTS AND DISCUSSION}

Collected water samples were initially maintained in Walne medium for a period of 20 days. After 20 days, the maximum growth was obtained and it was subjected to microscopic observation. Microscopic observation revealed that the sample contained Biddulphia (Odontella) sp. which is also known as the Chinese Diatom (Fig. 2). There were significant number of the mentioned species and no other species identified. Because, Biddulphia (Odontella) sp. produces blooms and may cause disruption to other phytoplankton species when it proliferates [7].

It is further confirmed by the identification manual of Hasle et al. [8]. Cells were observed either in isolated or in the colony which are organized in straight lines or in a zigzag pattern. They are yellow/brown in colour (Figs. 2 and 3). The size is varied from 25 to $40 \mu$.

Pure culture technique is in process to separate Biddulphia (Odontella) sp. from other cells debris by using phytoplankton net with varying sizes and molecular identification has planned in order to identify the species. Biddulphia (Odontella) sp. usually lives in sea waters with the temperature ranging from 2 to $12^{\circ} \mathrm{C}$ and a salinity ranging between 27 and 35 ppt [9]. Results of this study revealed that Biddulphia (Odontella) $\mathrm{sp}$. are also continue to exist and proliferated in normal phytoplankton laboratory conditions (Table 1).

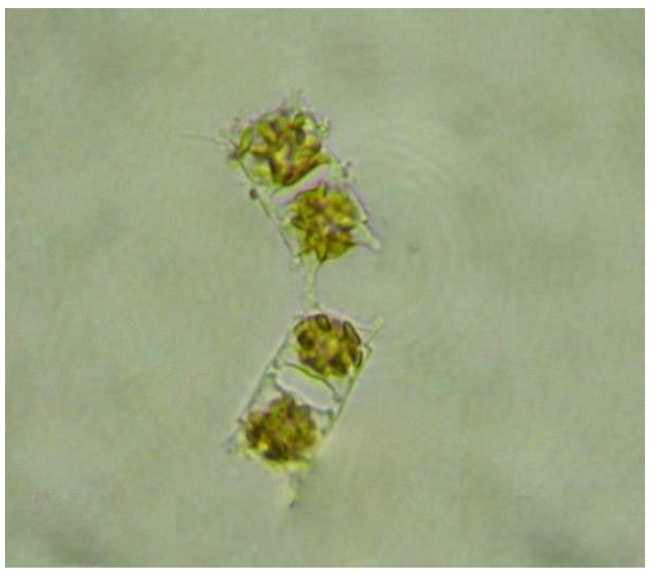

Fig. 2. Microscopic observation of isolated form of Biddulphia (Odontella) sp.
Table 1. Optimum parameters maintained for Biddulphia (Odontella) sp.

\begin{tabular}{ll}
\hline Parameters & Optima \\
\hline Temperature ( $\left.{ }^{\circ} \mathrm{C}\right)$ & $18-25$ \\
Salinity (ppt) & $27-35$ \\
Light intensity (lux) & $1000-2000$ \\
Photo period (I:d hours) & $16: 8$ (minimum) 24:0 \\
& (maximum) \\
pH & $8.2-8.7$ \\
\hline
\end{tabular}

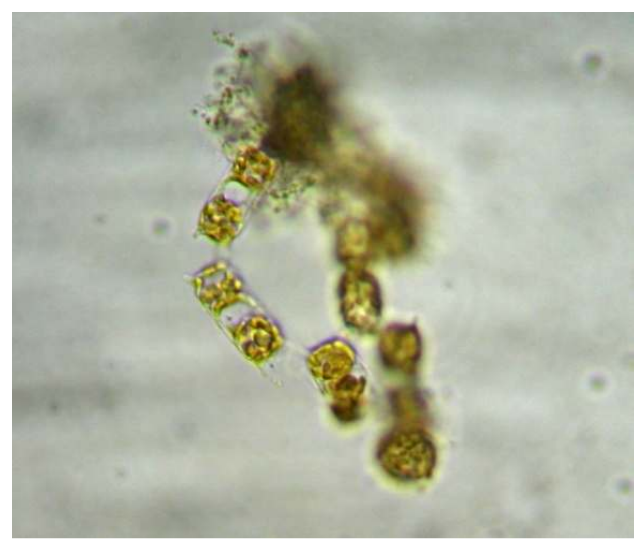

Fig. 3. Microscopic observation of colony form of Biddulphia (Odontella) sp.

In a balanced ecosystem, phytoplankton provides food for a wide range of sea creatures including whales, shrimp, snails, and jellyfish. Marine microalgae are the primary producers of n-3 PUFA in the marine food chain. Biddulphia (Odontella) sp. is known to contain high levels of EPA $(26 \%$ of total fatty acid) which is very important nutrient for aquatic animals [10].

It contains several bioactive compounds, such as pigments, fibers and phytosterols, which have beneficial effects on human health [11]. Biddulphia (Odontella) sp. is currently approved as a dietary supplement. The studies of Moreau et al. [11] focus on carotenoids extracted from Biddulphia (Odontella) sp., for anti proliferative effect in cultures of bronchopulmonary and epithelial cells. Other medicinal and nutritional profile of Biddulphia (Odontella) sp. is not much focused.

\section{CONCLUSION}

It has been widely used as a feed for zooplanktons but there is no much evidence for its potential in medicinal, nutritional and other properties. Therefore, further more research is 
needed in the aspect of medicinal, nutritional and other properties of Biddulphia (Odontella) sp. Moreover, there is no evidence about the maintenance of this species in research purpose. It has been maintained in Phytoplankton repository of Tuticorin Research Centre, ICARCMFRI for research and sale.

\section{ACKNOWLEDGEMENT}

Authors are thankful to the authorities of ICARCMFRI for their facilities and support.

\section{COMPETING INTERESTS}

Authors have declared that no competing interests exist.

\section{REFERENCES}

1. Omar WMW. Perspectives on the use of algae as biological indicators for monitoring and protecting aquatic environments, with special reference to Malaysian freshwater ecosystems. Trop Life Sci Res. 2010;21(2):51-67.

2. Zetsche EM, Ahmed El Mallahi, Filip JR Meysman. Digital holographic microscopy: A novel tool to study the morphology, physiology and ecology of diatoms. Diatom Res. 2016;31:1-16.

3. Allen MM. Simple conditions for growth of unicellular blue-green algae on plates. $J$ Phycol. 1968;4:1-4.

4. Arnon DI. Microelements in culture solution experiments with higher plants. Am $\mathrm{J}$ Bot. 1938;25:232-5.

5. Bold HC. The cultivation of algae. Bot Rev. 1942;8:69-138.
6. Burlew JS, ed. Algal culture: From laboratory to pilot plant. Carnegie Institution of Washington, Washington, DC. 1953;1-357.

7. Vivi Endar, Sarjito, Johannes Hutabarat, Budi Prayitn. Effect of using guillard and walne technical culture media on growth and fatty acid profiles of microalgae Skeletonema sp. In mass culture. J Coast Develop. 2012;16:50-56.

8. Gollasch S. Overview on introduced aquatic species in European navigational and adjacent waters. Helgoland Mar Res 2006;60(2):84-89.

9. Hasle GR, Syvertsen EE. Marine diatoms. Pages 3-385 in C. M. Tomas, editor. Identifying Marine Diatoms and Dinoflagellates. Academic Press. San Diego; 1997.

10. Wallentinus I. Introductions and transfers of plants. In Annex 8: Status of introductions of non-indigenous marine species to north Atlantic and adjacent waters according to national reports considered at meetings of the working group on introductions and transfers of marine organisms 1992-2002 of the report of the working group of introductions and transfers of marine organisms, Oostend, Belgium. 2006;16-17.

11. Moreau D, Tomasoni C, Cathrine J, Kaas R, Le Guedes R, Cadoret JP, MullerFeuga A, Kontiza I, Vagias C, Roussis V, Roussakis C. Cultivated microalgae and the carotenoid fucoxanthin from Odontella aurita as potent anti-proliferative agents in bronchopulmonary and epithelial cell lines. Environ Toxicol Pharmaco. 2006;22:97103.

(c) 2016 Lakshmana Senthil et al.; This is an Open Access article distributed under the terms of the Creative Commons Attribution License (http://creativecommons.org/licenses/by/4.0), which permits unrestricted use, distribution and reproduction in any medium, provided the original work is properly cited.

Peer-review history:

The peer review history for this paper can be accessed here: http://sciencedomain.org/review-history/16458 